\title{
Mental Distress and Associated Factors Among Undergraduate Engineering Students of Hawassa University, Ethiopia
}

This article was published in the following Dove Press journal: Journal of Multidisciplinary Healthcare

\author{
Yared Reta $\mathbb{D}^{\prime}$ \\ Tinbete Samuel ${ }^{2, *}$ \\ Mekedes Mekonnen ${ }^{2}$ ** \\ 'Department of Psychiatry, Hawassa \\ University, Hawassa, SNNPR, Ethiopia; \\ ${ }^{2}$ School of Nursing, Hawassa University, \\ Hawassa, SNNPR, Ethiopia \\ *These authors contributed equally to \\ this work
}

Background: Mental distress is a range of symptoms and experiences of a person's internal life that are commonly held to be troubling, confusing or out of the ordinary. Mental distress often interferes with studying, social interaction, and academic outcomes. Therefore, this study aimed at assessing the prevalence of mental distress and factors associated with it among undergraduate engineering students at Hawassa University.

Methods: We conducted an institution-based cross-sectional descriptive study on undergraduate engineering students at Hawassa University. We collected the data from January to April 30, 2018, using interviewer-administered Self-Report Questionnaire 20 (SRQ-20) from 341 participants selected by stratified sampling and we performed multiple logistic regression analysis to find factors associated with mental distress.

Results: Out of the total study population, 222 (65.1\%) were males, and 172 (50.4\%) were age $\geq 21$. We found the prevalence of mental distress using SRQ-20 with a cut-off point $\geq 8$ to be $28.7 \%$. Female students were 2.9 times more likely to have mental distress as compared to male students $(\mathrm{AOR}=2.90,95 \% \mathrm{CI}: 1.52-5.50)$. Facing financial problem $(\mathrm{AOR}=2.20 ; \mathrm{CI}=$ $1.25-3.85)$, poor social support $(\mathrm{AOR}=2.58,95 \% \mathrm{CI}: 1.51-4.42)$, lack of interest in their field of study $(\mathrm{AOR}=2.57$; $\mathrm{CI}: 1.23-5.38)$ and unresolved conflict with roommate $(\mathrm{AOR}=$ $2.29,95 \%$ CI: $1.08-4.00)$ were significant predictors of mental distress.

Conclusion: This study showed a high prevalence of mental distress among engineering students. So, policymakers, university officials, and parents need to give due attention to engineering undergraduate students for proactive measures.

Keywords: mental distress, engineering students, Hawassa, Ethiopia

\section{Introduction}

Although mental distress is referenced in health-care literature, the origin of the concept of mental distress or psychological distress is not defined as a discrete concept. ${ }^{1}$ The Diagnostic and Statistical Manual of Mental Disorders, Fifth Edition (DSM-5) defines the term psychological distress as "A range of symptoms and experiences of a person's internal life that are held to be troubling, confusing, or out of the ordinary". 2

University students have a high level of psychological distress more than the public, and mental distress has been the most common disabling condition among university students in the world. ${ }^{3-5}$ This higher predisposition to mental distress might be because students are prone to stressors like; pressure from family and teachers to succeed, competitions with peers, exams, financial issues, separation from family, living in
Correspondence: Yared Reta Email yaredr2002@yahoo.com 
a new environment, and lack or shortage of facilities for entertainment. ${ }^{6,7}$ When a student experiences high or chronic stress, it can interfere with her/his ability to learn, memorise, and good grades. Intense pressure may cause severe mental illness in particular depression and debilitate physical health. ${ }^{8,9}$

The study conducted by the World Health Organization (WHO) with a sample of 1,572 participants from 21different countries (lower to upper-income countries) showed that one-fifth (20.3\%) of college students had mental disorders; The majority (83.1\%) had prematriculation onsets and only $16.4 \%$ of students received mental healthcare. ${ }^{5}$

According to studies in the USA, $15.6 \%$ of undergraduates and $13.0 \%$ of graduate students experienced anxiety or depression. ${ }^{10}$ In Australia, one study showed a higher prevalence of mental distress among undergraduate students $(53.0 \%){ }^{4}$ A study from 16 Canadian universities $(n=7800)$ stated that $30 \%$ of the students have high psychological distress. ${ }^{11}$ In Malaysia $41.9 \%$ and Brazil, $49.1 \%$ of medical students found to have emotional distress. ${ }^{12,13}$

A cross-sectional comparative study determining stress level between medical and non-medical students showed that $54.6 \%$ of medical and $20.6 \%$ of undergraduate engineering students suffer from high stress in Karachi, Pakistan. ${ }^{14}$ A study from the Engineering College of Rajasthan, India, showed that $24.5 \%$ of undergraduate engineering students have a mental illness. ${ }^{15}$ In Africa, research conducted in Nigeria showed a $36.9 \%$ prevalence of general psychiatric morbidity among undergraduate students. In Egypt, a study among medical students $(n=700)$ showed psychological stress of $59.9 \%{ }^{16}$ Research from Uganda shows the level of stress among health science students was $57.4 \%$ and a study from Zimbabwe reported a Higher prevalence of mental distress $(64.5 \%)$ amongst first-year medical students. ${ }^{16,17}$ In Somaliland at the University of Hargeisa, a lower prevalence of mental distress was reported $(19.8 \%){ }^{18}$

In Ethiopia, a study done among 10,203 residents of Addis Ababa using SRQ-20 revealed a prevalence of mental distress $11.7 \%{ }^{19}$ Another most recent study with a larger sample size $(n=2180)$ done in the same town using the same tool but restricted to the adult population showed a prevalence of mental distress to be $17.7 \% .^{20}$ Three studies using SRQ-20 showed a prevalence of mental distress among medical students to be; $29.2 \%$ at Mizan Aman Health Science College, $30 \%$ at Hawassa University and $32.6 \%$ at Addis Ababa University. A study done at Adama University and Gondar University reported a prevalence of mental distress $21.6 \%$ and $40.9 \%$, respectively. ${ }^{24,25}$

Studies showed different factors can affect mental distress among students. Studies from Gondar (AOR $=1.65$, 95\% CI: 1.17-2.30) and Axum (AOR =1.7, 95\% CI: 1.20-2.34) universities of Ethiopia showed that the odds of having mental distress is higher in females than in males. ${ }^{25,26}$ An Indian study reported a significantly higher prevalence of psychological distress on people living in rural areas than people from urban areas. ${ }^{27}$ Never attending religious practice was an important predictor of mental distress $^{24,25}$ and studies from Adama and Axum Universities evidenced that students with a family history of mental illness have higher odds of mental distress.

Being a freshman student $(\mathrm{AOR}=1.73,95 \% \mathrm{CI}: 1.10$, 2.71) was associated with mental distress in the Axum University study. ${ }^{26}$ In the meantime, a study from Adama University revealed that the odds of having mental distress is less among second-year students as compared to thirdyear students $(\mathrm{AOR}=0.41,95 \% \mathrm{CI}: 0.18-0.91){ }^{24}$

Students with poor CGPA $(\mathrm{AOR}=2.07$, 95\% CI: 1.51-2.83) and students who lack interest in their field of study $(\mathrm{AOR}=2.28,95 \% \mathrm{CI}: 1.49-3.50)$ have higher odds of having mental distress than their counterparts. ${ }^{25}$ Financial distress and lack of social support were the other factors that may lead students to mental distress ${ }^{25,26}$ and Conflict with friends and Khat use were the other reported important predictors of mental distress. ${ }^{24-26}$

Starting from 2009 to 2010, Ethiopian Mistry of education implemented 70:30 student placement policy that is, $70 \%$ catering for Science and Technology students and $30 \%$ for humanities and social sciences. ${ }^{28,29}$ This placement strategy symbolises the shift of emphasis towards Engineering by the government market-driven decision to divide $70 \%$ of new students to engineering-related faculties and institutions irrespective of students' preferences.

In Ethiopia, unfulfilled facilities, overcrowded classrooms and prolonged school year can lead to stressful environments for Science and Technology students. Despite the 70:30 student placement teaching policy, most teaching staff and university management lack confidence in the competence of their graduates, reflecting the lack of a university quality assurance program and the increasing number of students in science and technology. ${ }^{30,31}$ Although the Ethiopian ministry of education (EMoE) has been implementing these programs for decades, to the best of the authors' knowledge, there is no study done in Ethiopia 
regarding mental distress among engineering undergraduate students.

Therefore, this study measures the level of mental distress and examines the relationships of various factors with mental distress among engineering students. Findings from this study could resolve the information gap about the prevalence of mental distress and factors associated with it, provide other researchers with valuable information to build on and findings could be a valuable asset in identifying information gaps for university officials and policymakers.

\section{Methods and Materials Study Design and Setting}

We used an institution-based quantitative cross-sectional study at the Institute of Technology (IOT) campus, Hawassa University, Ethiopia, from January - April 30, 2018. Hawassa University, the only university found in Hawassa, has six campuses each with different fields of study and centre of excellence. One campus is the Institute of Technology campus which has 12 departments and the IOT campus registrar office reported the most recent number of undergraduate engineering students from every academic year and all departments are 5448.

\section{Participants and Sample Size}

We used a single-population proportion formula to calculate the sample size. Taking into account the prevalence of mental distress of $40.9 \%{ }^{25}$ and $5 \%$ as the minimal difference with $95 \%$ confidence of certainty, the calculated sample size was 371. Since the source population is 5448 , which is less than 10,000 , we used a correction formula and the sample size is calculated to be 348 . Overall, with a non-response rate of $10 \%$, the total sample size was 383.

After getting a list of students' names who are enrolled and available during the data collection period from the IOT campus registrar office, we randomly selected study participants (using OpenEpi Random Number Generator).

\section{Data Collection Procedure Study Variables}

Mental distress is the outcome variable. The exposure variables included: Socio-demographic and economic factors such as sex, age, religion, the place of residence (urban or rural), a distance of the students' home from the university, family visit and family history of mental illness, pocket money, and facing financial problems.

Academic characteristics include variables such as the year of study, the field of study, cumulative grade point average (CGPA), choice of and interest in the field of study. We also included social support, unresolved conflict with a roommate, current use of a substance (use with in the past 30days), poly or single substance use and age of first use.

\section{Measurements}

We collected the data using a structured self-administered questionnaire which includes: a structured question of socio-demographic, economic, educational and substance use characteristics of the students; The next part of the questionnaire has Oslo-3 item social support scale with items sum $>9$ showing good social support; We used the English version SRQ-20 to measure mental distress. ${ }^{32,33}$

World Health Organization (WHO) developed SRQ-20 as an instrument to screen mental distress, for developing countries. It has 20 "YES" or "NO" questions, and plausible to use it as a self-administered or intervieweradministered questionnaire. ${ }^{34}$

We score each item 0 or 1 , where one means that the symptoms were present and 0 means the symptom was absent for the past 30 days; so, the greatest score is 20 out of 20 , and the least score is 0 out of 20. The tool was validated in low and middle-income countries including Ethiopia $^{26,27}$ and we used the cut-off point based on the reports from the validation study of SRQ-20 that gave the highest sensitivity and specificity at a cut-off point $8 .^{34}$

To make sure completeness and consistency inflow of items, to minimise systematic errors and to estimate the time needed to complete the questionnaire; We pre-tested the questionnaire on $5 \%$ of a similar population in another department before the actual data collection.

\section{Statistical Analysis}

We checked the data completeness and entered it to Epi-Data (Classic) Entry version 3.1 and exported the data to IBM SPSS version 24 for cleaning and further analysis. We used percentages and frequencies to present descriptive statistics. Associated variables in bivariate logistic regression $(\mathrm{P}<0.05)$, were computed to multiple logistic regression to control confounders. We used the adjusted odds ratio to measure the strength of the relationship between explanatory and outcome variables at a significance level $<0.05$. 


\section{Result}

\section{Socio-Demographic and Socio-Economic} Characteristics

From 383 participants, we got completed data for 341 respondents (Response rate: 89\%). Two hundred and twenty-two $(65.1 \%)$ were male students, and of all participants, 277 (81.2\%) are single. Half 172 (50.4\%) of the study participants were age $\leq 21$ years. Two hundred and twenty-six (66.3\%) were Orthodox Christians, followed by 76 (22.3\%) Protestants. Most of the respondents 282 $(82.7 \%)$, have a habit of attending religious practices in which $106(31.1 \%)$ of the students had a habit of attending religious practice at least once in a week and 84 (24.6\%) of the students have a habit of attending religious practice every day. Seventeen $(5 \%)$ of the students have a family history of mental illness and $86(25.2 \%)$ visit their families at least twice a year (Table 1).

The majority, 278 (81.5\%) undergraduate engineering students in the campus came from urban areas of Ethiopia, and $68(20.0 \%)$ came from very remote places of Ethiopia to join the university. One hundred and one (29.6\%) of the participants get a high amount of pocket money $(>700$ Ethiopian Birr (ETB)) and 44 (12.9\%) of participants get the lowest amount of pocket money $(<400$ ETB). One hundred and twenty-seven (37.2\%) of the students reported that they have been facing financial problems in the time being (Table 1).

\section{Academic, Social Support and Substance Use Characteristics}

Most students were from the Department of Civil Engineering, $100(29.3 \%)$ followed by students from Electromechanical Engineering 64 (18.8\%). While looking at sample distribution through the academic year, 104 (30.5\%) of the participants were second-year students followed by $94(27.6 \%)$, first-year students and $14.6 \%$ of the participants were graduate class. Eighty-eight (25.8\%) of participants have a cumulative grade point average score range between 2.51 and 3.00 , followed by $72(21.1 \%)$ of the students' CGPA score between 3.01 and 3.50 and eight students have CGPA $<2.00$. Meanwhile, 280 (82.1\%) joined their field by their own choice and 293 (85.9\%) have an interest in their field of study (Table 2).

According to social support, 173 (50.7\%) scored $>9$ or have good social support on the Oslo social support scale and $135(39.7 \%)$ of undergraduate engineering students have had an unresolved conflict with one or more of
Table I Frequency and Percentage Distribution of Sociodemographic and Economic Characteristics of Hawassa University Engineering Students, Ethiopia, April 2018

\begin{tabular}{|c|c|c|c|}
\hline Variable & $\begin{array}{l}\text { Specific } \\
\text { Variable }\end{array}$ & Frequency & $\%$ \\
\hline Sex & $\begin{array}{l}\text { Male } \\
\text { Female }\end{array}$ & $\begin{array}{l}222 \\
119\end{array}$ & $\begin{array}{l}65.1 \% \\
34.9 \%\end{array}$ \\
\hline Age & $\begin{array}{l}\leq 21 \\
>21\end{array}$ & $\begin{array}{l}172 \\
169\end{array}$ & $\begin{array}{l}50.4 \% \\
49.6 \%\end{array}$ \\
\hline Relation-ship status & $\begin{array}{l}\text { Single } \\
\text { In } \\
\text { relationship } \\
\text { Married }\end{array}$ & $\begin{array}{l}277 \\
54 \\
10\end{array}$ & $\begin{array}{l}81.2 \% \\
15.9 \% \\
2.9 \%\end{array}$ \\
\hline Place of residence & $\begin{array}{l}\text { Urban } \\
\text { Rural }\end{array}$ & $\begin{array}{l}278 \\
63\end{array}$ & $\begin{array}{l}81.5 \% \\
18.5 \%\end{array}$ \\
\hline $\begin{array}{l}\text { Distance of the university from the } \\
\text { student's homeland }\end{array}$ & $\begin{array}{l}\text { Near } \\
\text { Not that far } \\
\text { Far } \\
\text { Very far }\end{array}$ & $\begin{array}{l}69 \\
115 \\
89 \\
68\end{array}$ & $\begin{array}{l}20.2 \% \\
33.7 \% \\
26.1 \% \\
20.0 \%\end{array}$ \\
\hline Religion & $\begin{array}{l}\text { Orthodox } \\
\text { Christian } \\
\text { Protestant } \\
\text { Muslim } \\
\text { Others* }\end{array}$ & $\begin{array}{l}226 \\
76 \\
28 \\
11\end{array}$ & $\begin{array}{l}66.3 \% \\
22.3 \% \\
8.2 \% \\
3.2 \%\end{array}$ \\
\hline Attending religious practice & $\begin{array}{l}\text { Yes } \\
\text { No }\end{array}$ & $\begin{array}{l}282 \\
59\end{array}$ & $\begin{array}{l}82.7 \% \\
17.3 \%\end{array}$ \\
\hline $\begin{array}{l}\text { Frequency of attending religious } \\
\text { practice }\end{array}$ & $\begin{array}{l}\text { Every day } \\
\text { Weekly } \\
\text { Occasionally } \\
\text { Not at all }\end{array}$ & $\begin{array}{l}84 \\
106 \\
92 \\
59\end{array}$ & $\begin{array}{l}24.6 \% \\
31.1 \% \\
27.0 \% \\
17.3 \%\end{array}$ \\
\hline Frequency of family visit & $\begin{array}{l}4 \text { times } \\
\text { a year } \\
3 \text { times } \\
\text { a year } \\
2 \text { times } \\
\text { a year } \\
\text { Once a year }\end{array}$ & $\begin{array}{l}101 \\
65 \\
86 \\
71\end{array}$ & \begin{tabular}{r|}
$29.6 \%$ \\
$19.1 \%$ \\
$25.2 \%$ \\
$20.8 \%$
\end{tabular} \\
\hline Family history of mental illness & $\begin{array}{l}\text { Yes } \\
\text { No }\end{array}$ & $\begin{array}{l}17 \\
324\end{array}$ & $\begin{array}{l}5 \% \\
95 \%\end{array}$ \\
\hline Monthly pocket money & $\begin{array}{l}\text { Low }<400 \\
\text { Moderate } \\
400-700 \\
\text { High }>700 \\
\text { Non } \\
\text { response }\end{array}$ & $\begin{array}{l}44 \\
89 \\
101 \\
107\end{array}$ & $\begin{array}{l}12.9 \% \\
26.1 \% \\
29.6 \% \\
31.4 \%\end{array}$ \\
\hline Facing financial problem & $\begin{array}{l}\text { Yes } \\
\text { No }\end{array}$ & $\begin{array}{l}127 \\
214\end{array}$ & $\begin{array}{l}37.2 \% \\
62.8 \%\end{array}$ \\
\hline
\end{tabular}

Note: *Adventist, Catholic \& Apostolic.

their roommates'. Sixty-one (17.9\%) of participants used substance within the past 30 days, out of which, 24 $(39.3 \%)$ were polysubstance users. Students use the 
substance as of their first-time at the mean (SD) age of 17 ( \pm 3$)$ (Table 2).

\section{Mental Distress and Associated Factors}

Prevalence of mental distress using SRQ-20, with a cut-off point 8 and above is $28.7 \%$, and the internal consistency of SRQ-20 was $\propto=0.87$. The odds of having mental distress are 2.9 times more likely with females than males $(\mathrm{AOR}=$ 2.90; $\mathrm{CI}=1.52-5.50)$, and students who lack interest in their field of study are 2.6 times more likely to have mental distress as compared to their counterparts $(\mathrm{AOR}=$ 2.57, 95\% CI=1.23-5.38). Besides, students with poor social support were 2.6 times more likely to have mental distress compared to that of students with good social support $(\mathrm{AOR}=2.58,95 \% \mathrm{CI}: 1.51-4.42)$. Students who face financial problems were 2.2 times more likely to develop mental distress than students with good financial status $(\mathrm{AOR}=2.20 ; \mathrm{CI}=1.25-3.85)$. The odds of having mental distress were 2.3 times more likely in students having an unresolved conflict with a roommate $(\mathrm{AOR}=$ 2.29, 95\% CI: $1.08-4.00)$.

Age, having a family history of mental illness, not joining the field of study by choice, year of study, current use of a substance and distance of the university from the student's homeland were not significantly associated with mental distress in multiple logistic regression (Table 3).

\section{Discussion}

In this study, $28.7 \%$ of the study participants were found to have mental distress, and this finding is consistent with similar studies among medical students in Ethiopia (29.2\% at Mizan Aman Health Sciences College, 30\% at Hawassa University and $32.6 \%$ at Addis Ababa University) and with the study from Canada. ${ }^{11}$ The prevalence of mental distress in our study is higher than the prevalence in the general population (11.7\% and 17.7\%) of Addis Ababa. ${ }^{19,20}$ As explained by previous comparative studies, factors like; academic pressure, a stressful campus environment and substance use could be the reasons behind high mental distress in students than the general population. ${ }^{4,7}$

Mental distress prevalence in our study is lower than previous studies done in Gondar university (40.9\%) this can be because of the variation in the time frame, and the survey of Gondar university included study participants from different fields of study $(\mathrm{n}=872) .{ }^{25}$ Our study participants have higher mental distress than undergraduate engineering students in Karachi, Pakistan $(20.6 \%)^{14}$ and Rajasthan, India (24.5\%), ${ }^{15}$ this could be explained by both studies used different data
Table 2 Description of Academic, Social Support and Substance Use Characteristics of Hawassa University Engineering Students, Ethiopia, April 2018

\begin{tabular}{|c|c|c|c|}
\hline Variable & $\begin{array}{l}\text { Specific } \\
\text { Variable }\end{array}$ & Frequency & $\%$ \\
\hline Academic year & $\begin{array}{l}\text { Ist year } \\
\text { 2nd year } \\
\text { 3rd year } \\
\text { 4th year } \\
\text { 5th year }\end{array}$ & $\begin{array}{l}94 \\
104 \\
75 \\
18 \\
50\end{array}$ & $\begin{array}{l}27.6 \% \\
30.5 \% \\
22.0 \% \\
5.3 \% \\
14.6 \%\end{array}$ \\
\hline Field of study & $\begin{array}{l}\text { Civil } \\
\text { Electrical } \\
\text { Chemical } \\
\text { Electromechanical } \\
\text { Mechanical } \\
\text { Construction } \\
\text { Management } \\
\text { Hydraulics } \\
\text { Others* }\end{array}$ & $\begin{array}{l}100 \\
36 \\
64 \\
32 \\
30 \\
24 \\
45 \\
10\end{array}$ & $\begin{array}{l}29.3 \% \\
10.6 \% \\
18.8 \% \\
9.4 \% \\
8.8 \% \\
7.0 \% \\
\\
13.2 \% \\
2.9 \%\end{array}$ \\
\hline Joining field by choice & $\begin{array}{l}\text { Yes } \\
\text { No }\end{array}$ & $\begin{array}{l}280 \\
61\end{array}$ & $\begin{array}{l}82.1 \% \\
17.9 \%\end{array}$ \\
\hline $\begin{array}{l}\text { Interest in the field of } \\
\text { study } \\
\text { Cumulative grade point }\end{array}$ & $\begin{array}{l}\text { Yes } \\
\text { No } \\
<2.00 \\
2.00-2.5 \\
2.51-3.00 \\
3.01-3.50 \\
>3.50 \\
\text { No reported }\end{array}$ & $\begin{array}{l}293 \\
48 \\
8 \\
45 \\
88 \\
72 \\
30 \\
98\end{array}$ & $\begin{array}{l}85.9 \% \\
14.1 \% \\
2.3 \% \\
13.2 \% \\
25.8 \% \\
21.1 \% \\
8.8 \% \\
28.8 \%\end{array}$ \\
\hline Social support & $\begin{array}{l}\text { Good } \\
\text { Poor }\end{array}$ & $\begin{array}{l}173 \\
168\end{array}$ & $\begin{array}{l}50.7 \% \\
49.3 \%\end{array}$ \\
\hline $\begin{array}{l}\text { Unresolved conflict } \\
\text { with roommate }\end{array}$ & $\begin{array}{l}\text { Yes } \\
\text { No }\end{array}$ & $\begin{array}{l}135 \\
204\end{array}$ & $\begin{array}{l}39.7 \% \\
60.3 \%\end{array}$ \\
\hline Current substance use & $\begin{array}{l}\text { Yes } \\
\text { No }\end{array}$ & $\begin{array}{l}61 \\
280\end{array}$ & $\begin{array}{l}17.9 \% \\
82.1 \%\end{array}$ \\
\hline Substance used & $\begin{array}{l}\text { Single substance } \\
\text { only } \\
\text { Polysubstance use }\end{array}$ & $\begin{array}{l}37 \\
24\end{array}$ & $\begin{array}{l}60.7 \% \\
39.3 \%\end{array}$ \\
\hline
\end{tabular}

Note: *Water supply and Environmental, Bio-system and water resource, and irrigation.

instrument than SRQ-20 and have different socio-economic ground. The Pakistan study was a comparative study that only took a sample of 50 engineering students.

Similar to that of the earlier studies, the odds of having mental distress is higher in females than males $(\mathrm{AOR}=2.90$; $\mathrm{CI}=1.52-5.50){ }^{5,18-22,25,35}$ The interaction between different biological (hormonal changes in the menstrual cycle and females' nature of affective stress reaction) and psychosocial factors can explain the higher odds in females. ${ }^{36-38}$ Our study 
Table 3 Bivariate and Multiple Logistic Regression Analysis Showing Significant Predictors of Mental Distress Among Hawassa University Engineering Students, Ethiopia, April 2018

\begin{tabular}{|c|c|c|c|c|c|}
\hline \multicolumn{2}{|l|}{ Variable $(\mathrm{N}=\mathbf{3 4} \mathrm{I})$} & \multicolumn{2}{|c|}{ Mental Distress } & \multicolumn{2}{|l|}{ OR with $95 \% \mathrm{Cl}$} \\
\hline & & Yes & No & Crude & Adjusted \\
\hline Sex & $\begin{array}{l}\text { Male } \\
\text { Female }\end{array}$ & $\begin{array}{l}54 \\
44\end{array}$ & $\begin{array}{l}168 \\
75\end{array}$ & $\begin{array}{l}\text { I } \\
1.82 *(1.12,2.96)\end{array}$ & $2.90 *(1.52,5.50)$ \\
\hline Age of the students & $\begin{array}{l}\leq 21 \\
>21\end{array}$ & $\begin{array}{l}55 \\
43\end{array}$ & $\begin{array}{l}117 \\
126\end{array}$ & $\begin{array}{l}1.38(0.86,2.21) \\
\mathrm{I}\end{array}$ & $\begin{array}{l}1.26(0.70,2.27) \\
\mathrm{I}\end{array}$ \\
\hline Attending religious practice & $\begin{array}{l}\text { Yes } \\
\text { No }\end{array}$ & $\begin{array}{l}76 \\
22\end{array}$ & $\begin{array}{l}206 \\
37\end{array}$ & $\begin{array}{l}\text { I } \\
\text { I.6I }(0.89,2.90)\end{array}$ & $\begin{array}{l}\text { I. } \\
1.30(0.65,2.64)\end{array}$ \\
\hline Distance of the university from the student's homeland & $\begin{array}{l}\text { Near } \\
\text { Not that far } \\
\text { Far } \\
\text { Very Far }\end{array}$ & $\begin{array}{l}12 \\
35 \\
30 \\
21\end{array}$ & $\begin{array}{l}57 \\
80 \\
59 \\
47\end{array}$ & $\begin{array}{l}\text { I } \\
2.08(0.99,4.34) \\
2.41 *(1.12,5.18) \\
2.12(0.95,4.76)\end{array}$ & $\begin{array}{l}\text { I } \\
\text { I.77 }(0.78,4.03) \\
2.24(0.96,5.22) \\
\text { I.96 (0.79,4.84) }\end{array}$ \\
\hline Facing financial Problem & $\begin{array}{l}\text { Yes } \\
\text { No }\end{array}$ & $\begin{array}{l}48 \\
49\end{array}$ & $\begin{array}{l}79 \\
164\end{array}$ & $\begin{array}{l}2.03 *(1.26,3.29) \\
1\end{array}$ & $\begin{array}{l}2.20 *(1.25,3.85) \\
1\end{array}$ \\
\hline Family history of mental illness & $\begin{array}{l}\text { Yes } \\
\text { No }\end{array}$ & $\begin{array}{l}8 \\
90\end{array}$ & $\begin{array}{l}9 \\
234\end{array}$ & $\begin{array}{l}2.31(0.87,6.18) \\
I\end{array}$ & $\begin{array}{l}\text { I.53 }(0.53,4.43) \\
\text { I }\end{array}$ \\
\hline Joining field by choice & $\begin{array}{l}\text { Yes } \\
\text { No }\end{array}$ & $\begin{array}{l}76 \\
22\end{array}$ & $\begin{array}{l}204 \\
39\end{array}$ & I. $.5 \mid *(0.84,2.72)$ & $\begin{array}{l}\text { I } \\
0.83(0.41,1.67)\end{array}$ \\
\hline Interest in the field of study & $\begin{array}{l}\text { Yes } \\
\text { No }\end{array}$ & $\begin{array}{l}74 \\
24\end{array}$ & $\begin{array}{l}219 \\
24\end{array}$ & $2.96 *(1.59,5.52)$ & $\begin{array}{l}\text { I } \\
2.57 *(1.23,5.38)\end{array}$ \\
\hline Social support & $\begin{array}{l}\text { Good } \\
\text { Poor }\end{array}$ & $\begin{array}{l}33 \\
65\end{array}$ & $\begin{array}{l}140 \\
103\end{array}$ & $\begin{array}{l}\text { I } \\
2.67 * *(1.64,4.37)\end{array}$ & $\begin{array}{l}\text { I } \\
2.58 * *(1.51,4.42)\end{array}$ \\
\hline Unresolved conflict with roommate & $\begin{array}{l}\text { Yes } \\
\text { No }\end{array}$ & $\begin{array}{l}52 \\
46\end{array}$ & $\begin{array}{l}84 \\
159\end{array}$ & $\begin{array}{l}2.14 *(1.33,3.45) \\
1\end{array}$ & $\begin{array}{l}2.29 *(1.32,3.99) \\
1\end{array}$ \\
\hline Current substance use & $\begin{array}{l}\text { Yes } \\
\text { No }\end{array}$ & $\begin{array}{l}23 \\
75\end{array}$ & $\begin{array}{l}38 \\
205\end{array}$ & $\begin{array}{l}1.65(0.92,2.96) \\
1\end{array}$ & $\begin{array}{l}1.81(0.91,3.60) \\
1\end{array}$ \\
\hline
\end{tabular}

Notes: ${ }^{*} \mathrm{p}<0.05 ; * * \mathrm{P}<0.01 ; \mathrm{I}=$ Reference.

Abbreviation: OR, odds ratio.

showed that lack of interest in the field of study is an essential factor of mental distress; students who lack interest in their field of study are 2.6 times more likely to have mental distress as compared to their counterparts $(\mathrm{AOR}=2.57$, $95 \% \mathrm{CI}=1.23-5.38$ ). This finding is consistent with other studies done in Ethiopia. ${ }^{25,26}$ This might be because of students who lack interest in the field of their study may end-up with chronic motivation that students lack the initiation to achieve better grades and this may expose them to psychological distress. ${ }^{39}$

Social support can improve mental and physical health through stress reduction by catharsis and poor social support leads to stress which alters the physiological homeostasis of the hypothalamic-pituitary-adrenocortical (HPA) system. $^{40,41}$ Our study showed that students with poor social support were 2.6 times more likely to have mental distress compared to students with good social support $(\mathrm{AOR}=2.58,95 \% \mathrm{CI}: 1.51-4.42)$. This is supported by studies from Gondar and Axum University. ${ }^{25,26}$

Students who face financial problems were 2.2 times more likely to develop mental distress than students with good financial status $(\mathrm{AOR}=2.20 ; \mathrm{CI}=1.25-3.85)$. This finding is in line with results from different studies in Ethiopian universities. ${ }^{23,25,26}$ This might be for a reason that student's face financial constraints to buy necessary stationery materials these might lead to frustration, anxiety, and feeling of inefficient. ${ }^{42}$

Similar to studies from Gondar and Adama universities, ${ }^{24,25}$ our data showed that the odds of having mental distress were two times more likely in students having 
an unresolved conflict with a roommate than students not $(\mathrm{AOR}=2.078,95 \% \mathrm{CI}=1.078-4.003)$. This can be explained by the fact that disputes may cause greater stress and physical limitations. Stress can reduce the immune system and lead to several health conditions. ${ }^{43}$

Unlike other previous studies; year of study, scoring lower grades and having financial problems statistically has no significant association with mental distress. ${ }^{23-25,44}$ This can be because of the variation in the study population, and we conducted our study only among engineering students; the result may not be conclusive to all students attending higher Ethiopian institutions. Nevertheless, our study shows the current status of mental distress among engineering students, which can be generalised to institutions of similar setups in Ethiopia and this finding may benefit the $\mathrm{EMoH}$ in suggesting a plan of re-evaluating higher education student deployment policy and encourages researchers to develop a robust study to improve mental distress among undergraduate engineering students.

This study has certain potential drawbacks. Since we used a cross-sectional study design, the study does not allow inferring the causation. This study was not a comparative study which could not provide an enormous wealth of information on the prevalence rate of mental distress amongst different university population in Ethiopia.

\section{Conclusion}

This study provides evidence of a high prevalence of mental distress among undergraduate engineering students at Hawassa University (28.7\%) which is comparable to other stressful fields of study, such as that of a medical study.

The odds of having mental distress are higher in female students, students with financial problems, poor social support, and students who have an unresolved conflict with their roommates. Therefore, policymakers, university officials, and parents need to give due attention to undergraduate engineering students with prioritising risky groups for early intervention and proactive measures. We also recommend

\section{Abbreviations}

CGPA, Cumulative Grade Point Average; DSM-5, Diagnostic and Statistical Manual of Mental Disorders, Fifth Edition; EMoE, Ethiopian Ministry of Education; ETB, Ethiopian Birr; IOT, Institute of Technology; SRQ20, Self-Report Questionnaire 20; USA, United States of America; WHO, World Health Organization.

\section{Data Sharing Statement}

All essential data generated or analysed during this study are included in this published article. However, supplementary datasets are available from the corresponding author on a reasonable request.

\section{Ethics Approval and Consent to Participate}

The study was conducted in accordance with the Declaration of Helsinki and we obtained ethical clearance from Hawassa University College of Medicine and Health Sciences Institutional Review Board. The right of the participants to refuse or discontinue participation was respected and confidentiality was ensured. All respondents signed written informed consent before taking part in the research.

\section{Acknowledgment}

We want to extend our special gratitude to Hawassa University College of Medicine and Health Science for supporting the whole research project. Our sincere thanks go to the IOT campus registrar office for their dedicated collaboration and we are grateful and appreciate all research participants for their unreserved participation.

\section{Author Contributions}

All authors contributed to data analysis, drafting and revising the article, gave final approval of the version to be published, and agree to be accountable for all aspects of the work.

\section{Funding}

Hawassa University, College of Health Science financially supported the work. The write-up and the contents of this study are only the responsibility of the authors and may not represent views of Hawassa University, College of Health Science.

\section{Disclosure}

All authors declared no conflicts of interest in this work.

\section{References}

1. Ridner SH. Psychological distress: concept analysis. J Adv Nurs. 2004;45(5):536-545. doi:10.1046/j.1365-2648.2003.02938.x

2. APA. Diagnostic and Statistical Manual of Mental Disorders (DSM$\left.5^{\circledR}\right)$. American Psychiatric Pub; 2013.

3. Cvetkovski S, Reavley NJ, Jorm AF. The prevalence and correlates of psychological distress in Australian tertiary students compared to their community peers. Aust N Z J Psychiatry. 2012;46(5):457-467. doi: $10.1177 / 0004867411435290$ 
4. Stallman HM. Psychological distress in university students: a comparison with general population data. Aust Psychol. 2010;45 (4):249-257. doi:10.1080/00050067.2010.482109

5. Auerbach RP, Alonso J, Axinn WG, et al. Mental disorders among college students in the World Health Organization world mental health surveys. Psychol Med. 2016;46(14):2955-2970. doi:10.1017/ S0033291716001665

6. Sreeramareddy CT, Shankar PR, Binu V, Mukhopadhyay C, Ray B, Menezes RG. Psychological morbidity, sources of stress and coping strategies among undergraduate medical students of Nepal. BMC Med Educ. 2007;7(1):26. doi:10.1186/1472-6920-7-26

7. Vaez M, de Leon AP, Laflamme L. Health-related determinants of perceived quality of life: a comparison between first-year university students and their working peers. Work. 2006;26(2):167-177.

8. Shankar NL, Park CL. Effects of stress on students' physical and mental health and academic success. Int J Sch Educ Psychol. 2016;4 (1):5-9. doi:10.1080/21683603.2016.1130532

9. Maajida Aafreen M, Vishnu Priya V, Gayathri R. Effect of stress on academic performance of students in different streams. Drug Invent Today. 2018;10(9).

10. Eisenberg D, Gollust SE, Golberstein E, Hefner JL. Prevalence and correlates of depression, anxiety, and suicidality among university students. Am J Orthopsychiatry. 2007;77(4):534-542. doi:10.1037/ 0002-9432.77.4.534

11. Adlaf EM, Gliksman L, Demers A, Newton-Taylor B. The prevalence of elevated psychological distress among Canadian undergraduates: findings from the 1998 Canadian campus survey. J Am Coll Health. 2001;50(2):67-72. doi:10.1080/07448480109596009

12. Mohd Sidik S, Rampal L, Kaneson N. Prevalence of emotional disorders among medical students in a Malaysian university. Asia Pac Fam Med. 2003;2(4):213-217. doi:10.1111/afm.2003.2.issue-4

13. Bassols A, Siqueira M, Carneiro BB, et al. Stress and coping in a sample of medical students in Brazil. Arch Clin Psychiatry (São Paulo). 2015;42(1):1-5. doi:10.1590/0101-60830000000038

14. Aamir IS. Stress level comparison of medical and nonmedical students: a cross sectional study done at various professional colleges in Karachi, Pakistan. Acta Psychopathologica. 2017;03:02. doi:10.4172/ 2469-6676

15. Pandey A, Adhikari B, Verma S, Bhojak M. Prevalence and correlates of psychiatric problems among engineering students. $J$ Universal Coll Med Sci. 2014;2(2):6-10. doi:10.3126/jucms.v2i2.11167

16. Fawzy M, Hamed SA. Prevalence of psychological stress, depression and anxiety among medical students in Egypt. Psychiatry Res. 2017;255:186-194. doi:10.1016/j.psychres.2017.05.027

17. Amanya SB, Nakitende J, Ngabirano TD. A cross-sectional study of stress and its sources among health professional students at Makerere University, Uganda. Nurs Open. 2018;5(1):70-76. doi:10.1002/ nop2.113

18. Hersi L, Tesfay K, Gesesew H, Krahl W, Ereg D, Tesfaye M. Mental distress and associated factors among undergraduate students at the University of Hargeisa, Somaliland: a cross-sectional study. Int J Ment Health Syst. 2017;11(1):39. doi:10.1186/s13033-0170146-2

19. Kebede D, Alem A, Rashid E. The prevalence and socio-demographic correlates of mental distress in Addis Ababa, Ethiopia. Acta Psychiatr Scand. 1999;100:5-10. doi:10.1111/acp. 1999.100.issue-S397

20. Gelaye B, Lemma S, Deyassa N, et al. Prevalence and correlates of mental distress among working adults in Ethiopia. Clin Pract Epidemiol Ment Health. 2012;8:126. doi:10.2174/1745017901 208010126

21. Alem A, Araya M, Melaku Z, Wendimagegn D, Abdulahi A. Mental distress in medical students of Addis Ababa University. Ethiop Med J. 2005;43(3):159-166.
22. Jini D. Mental distress and its associated factors among students of Mizan Aman Health Science College, Ethiopia. J Med Sci. 2017;17 (2):61-67. doi:10.3923/jms.2017.61.67

23. Melese B, Bayu B, Wondwossen F, et al. Prevalence of mental distress and associated factors among Hawassa University medical students, Southern Ethiopia: a cross-sectional study. BMC Res Notes. 2016;9(1):485. doi:10.1186/s13104-016-2289-7

24. Dessie Y, Ebrahim J, Awoke T. Mental distress among university students in Ethiopia: a cross sectional survey. Pan Afr Med J. 2013;15:1. doi:10.11604/pamj.2013.15.95.2173

25. Dachew BA, Bisetegn TA, Gebremariam RB. Prevalence of mental distress and associated factors among undergraduate students of University of Gondar, Northwest Ethiopia: a cross-sectional institutional based study. PLoS One. 2015;10(3):e0119464. doi:10.1371/ journal.pone.0119464

26. Tesfahunegn TB, Gebremariam EH. Mental distress and associated factors among Aksum University students, Ethiopia: a cross-sectional study. BMC Psychiatry. 2019;19(1):71. doi:10.1186/s12888-019-2051-5

27. Islam FMA. Psychological distress and its association with socio-demographic factors in a rural district in Bangladesh: a cross-sectional study. PLoS One. 2019;14(3):e0212765. doi:10. 1371/journal.pone.0212765

28. Girma T The 70: 30 student placement ratio and its implication towards Private Higher Education Institutions (PHEIs); 2011. http:// 197.156.93.91/handle/123456789/2201

29. ESDP I. Education Sector Development Program IV. Education Sector Development Program IV (2010/2011-2014/2015). Addis Ababa: Program Action Plan/PAP, Ministry of Education; 2010.

30. Tasisa W, Panigrahi MR Internal quality assurance of science and technology education in Ethiopian University; 2012.

31. Yibeltal Yizengaw J. Skills gaps and mismatches: private sector expectations of engineering graduates in Ethiopia. IDS Bulletin. 2018;49. doi:10.19088/1968-2016.100

32. Abiola T, Udofia O, Zakari M. Psychometric properties of the 3-item oslo social support scale among clinical students of Bayero University Kano, Nigeria. Malays J Psychiatry. 2013;22(2):32-41.

33. Beusenberg M, Orley JH; Organization WH. A User's Guide to the Self Reporting Questionnaire (SRQ). Geneva: World Health Organization; 1994.

34. Youngmann R, Zilber N, Workneh F, Giel R. Adapting the SRQ for Ethiopian populations: a culturally-sensitive psychiatric screening instrument. Transcult Psychiatry. 2008;45(4):566-589. doi:10.1177/ 1363461508100783

35. Soh NL-W, Norgren S, Lampe L, Hunt GE, Malhi GS, Walter G. Mental distress in Australian medical students and its association with housing and travel time. $J$ Contemp Med Educ. 2013;1:163-169. doi:10.5455/jcme.

36. Afifi M. Gender differences in mental health. Singapore Med J. 2007;48(5):385

37. Barron ML, Flick LH, Cook CA, Homan SM, Campbell C. Associations between psychiatric disorders and menstrual cycle characteristics. Arch Psychiatr Nurs. 2008;22(5):254-265. doi:10.1016/j.apnu.2007.11.001

38. Bayram N, Bilgel N. The prevalence and socio-demographic correlations of depression, anxiety and stress among a group of university students. Soc Psychiatry Psychiatr Epidemiol. 2008;43(8):667-672. doi:10.1007/s00127-008-0345-x

39. Roeser RW, Eccles JS, Freedman-Doan C. Academic functioning and mental health in adolescence: patterns, progressions, and routes from childhood. J Adolesc Res. 1999;14(2):135-174. doi:10.1177/07435 58499142002

40. Harandi TF, Taghinasab MM, Nayeri TD. The correlation of social support with mental health: a meta-analysis. Electron Physician. 2017;9(9):5212. doi:10.19082/5212 
41. Ozbay F, Johnson DC, Dimoulas E, Morgan C III, Charney D, Southwick S. Social support and resilience to stress: from neurobiology to clinical practice. Psychiatry (Edgmont). 2007;4(5):35.

42. Dashiff C, DiMicco W, Myers B, Sheppard K. Poverty and adolescent mental health. $J$ Child Adolesc Psychiatr Nurs. 2009;22 (1):23-32. doi:10.1111/j.1744-6171.2008.00166.x
43. CREO P Impact of interpersonal conflict on university students' mindset. https://extrudesign.com/impact-of-interpersonal-conflict-onuniversity-students-mindset/

44. Mehta K, Kaur S, Girgla KK, Kaur P, Kaur H. A study of mental distress in medical students. Natl $J$ Physiol Pharm Pharmacol. 2015;5(3):190. doi:10.5455/njppp.

\section{Publish your work in this journal}

The Journal of Multidisciplinary Healthcare is an international, peerreviewed open-access journal that aims to represent and publish research in healthcare areas delivered by practitioners of different disciplines. This includes studies and reviews conducted by multidisciplinary teams as well as research which evaluates the results or conduct of such teams or healthcare processes in general. The journal covers a very wide range of areas and welcomes submissions from practitioners at all levels, from all over the world. The manuscript management system is completely online and includes a very quick and fair peer-review system. Visit http://www.dovepress.com/testimonials. php to read real quotes from published authors. 